during 1931, has been issued by the Publications Committee, of which Mr. Hugh Cairns is honorary secretary. It contains $\mathbf{3 3}$ papers, all previously published elsewhere, which range over a wide field in the science and art of medicine. The London Hospital houses a wealth of clinical material, and the staff appears to have made full use of the opportunities for investigation and the publication of adequate records of unusual cases.

\section{Ross Institute}

THE annual report and accounts for 1931 of the Ross Institute and Hospital for Tropical Diseases, Putney Heath, London, S.W.15, shows a serious reduction in contributions in 1931. The Institute at present possesses no endowment fund, and the honorary treasurer, Lord Queenborough, appeals for generous financial support this year. The report also contains a summary of the research work carried out at the Institute, and an account of the results of malaria prevention abroad following measures suggested by the Malaria Department of the Institute.

\section{Announcements}

Prof. C. U. Arikins Kappers will deliver the David Ferrier Lecture at the Royal Society on June 2, taking as his subject "Some Correlations between the Brain and the Skull".

THE annual visitation of the Royal Observatory, Greenwich, will be held on Saturday, June 4, and of the National Physical Laboratory on Tuesday, June 28 .

Dr. E. F. Armstrong (chairman of Council) and Mr. J. Davidson Pratt (general manager) have been appointed representatives of the Association of British Chemical Manufacturers at the Imperial Conference at Ottawa.

A JOINT discussion on "Vision" has been arranged by the Physical and Optical Societies, to be held at the Imperial College of Science and Technology, South Kensington, S.W.7, on Friday, June 3, at 2.30-5.30 P.M. and 7-9.30 P.M. Twenty-eight papers by leading British and foreign contributors have been promised. Visitors will be welcomed; no tickets are required.

IT is announced in Science that Dr. E. C. Franklin, emeritus professor of organic chemistry at Stanford University, has been awarded the Willard Gibbs Medal for 1932 by the Chicago Section of the American Chemical Society for his "work on liquid ammonia solutions, [which] opened up an entirely new field, and also modified profoundly our views on aqueous solutions. He has made a life-long study, characterised by insight, thoroughness and experimental skill, of reactions in liquid ammonia."

The National Baby Week Council announces that 'national baby week' will be held this year on July 1-7. It is suggested that, in view of the present economic crisis, the subject of the economic values of maternity and child welfare work should find a place in local and national propaganda. The report of the Council for 1931 has been issued and gives details of the work accomplished during the year, the competitions organised in connexion with National Baby Week, and awards of the Baby Week challenge shields and prizes.

THE second supplement to the "Bibliography of Bibliographies on Chemistry and Chemical Technology" has been published by the National Research Council of the National Academy of Sciences, Washington, D.C., as Bulletin No. 86. This publication, which completes those previously issued in 1925 (No. 50) and 1929 (No. 71), and noticed in Nature, includes references, classified under subjects, of publications, both books and papers, which contain bibliographies of the subjects. It is a valuable and useful work, which deserves to be widely known, and we are glad to direct attention to the issue of a new supplement.

Applicatrons are invited for the following appointments, on or before the dates mentioned :-A chief veterinary inspector under the Ministry of Agriculture for Northern Ireland-The Secretary, Civil Service Commission, Stormont, Belfast (June 4). An assistant pathologist at the National Hospital, Queen Square-The Secretary, National Hospital, Queen Square, W.C.1 (June 4). A principal of the Cambridgeshire Technical School-The Education Secretary, County Hall, Cambridge (June 6). A lecturer in structural and mechanical engineering at the Constantine Technical College, MiddlesbroughThe Director of Education, Education Offices, Woodlands Road, Middlesbrough (June 6). A Morna Macleod research student in biochemistry at the Lister Institute of Preventive Medicine-. The Secretary, Lister Institute, Chelsea Bridge Road, S.W.I (June 7). A full-time lecturer in mining technology at the Clown Mining and Technical Institute-The Director of Education, County Education Office, St. Mary's Gate, Derby (June 8). A Duddell Scholar of the Institution of Electrical Engineers-The Secretary, Institution of Electrical Engineers, Savoy Place, W.C.2 (June 15). A Rhondda Research Student at Gonville and Caius College, Cambridge (open only to students who are residents or sons of residents in Wales or Monmouthshire)-The Master, Gonville and Caius College, Cambridge. A resident lecturer in biology (including gardening) at the Saffron Walden Training College for Women TeachersThe Principal, Training College for Women Teachers, Saffron Walden, Essex. A Leverhulme fellow for fishery research at University College, Hull-The Registrar, University College, Hull. Part-time lecturers in general biology and physiology, respectively, in the Applied Optics Department of the Northampton Polytechnic Institute-The Registrar, Northampton Polytechnic Institute, St. John Street, E.C.1. A director of the National Institute of Poultry Husbandry, Newport, Shropshire-The Principal, Harper Adams Agricultural College, Newport, Shropshire.

$$
\text { No. 3265, VoL. 129] }
$$

